\title{
PENGGUNAAN MEDIA MADDING UNTUK MENGASAH KEMAMPUAN KOGNITIF PESERTA DIDIK PADA MATERI KONSEP PERDAGANGAN INTERNASIONAL
}

\author{
DIAH ARUMSASI \\ SMA Negeri 2 Mranggen \\ e-mail : diaharumsasi3@gmail.com
}

\begin{abstract}
ABSTRAK
Tujuan Penelitian Kelas ini yaitu: (1) Mendeskripsikan Proses Pembelajaran dengan menggunakan Model Pembelajaran Inquiry untuk meningkatkan Kemampuan Kognitif Konsep Perdagangan Internasional Peserta Didik Kelas XI IPS 2. (2) Mendeskripsikan Seberapa banyak Peningkatan Peserta didik Kemampuan Kognitif Konsep Perdagangan Internasional yang ditunjukkan oleh nilai hasil belajar siswa dengan menggunakan Model Pembelajaran Inquiry pada Peserta Didik Kelas XI IPS 2. (3) Mendeskripsikan perubahan perilaku yang menyertai peningkatan kemampuan kognitif atau pemahaman Konsep Perdagangan Internasional terlalu luas dan seringkali update berkaitan dengan informasi Perdagangan Internasional berkaitan dengan kondisi negara di masyarakat, dengan menggunakan Model Pembelajaran Inquiry pada Peserta Didik Kelas XI IPS 2. SMA N 2 Mranggen, (4) Mendeskripsikan perubahan perilaku yang menyertai peningkatan motivasi belajar dan membaca yang kurang untuk memahami materi Perdagangan Internasional ini dengan menggunakan Model Pembelajaran Inquiry pada Peserta Didik Kelas XI IPS 2. SMA N 2 Mranggen. Berdasarkan hasil penelitian, diketahui Nilai Rata - rata untuk Ulangan Harian yang dijadikan sebagai Pra Siklus adalah 38,43, hanya 1 siswa yang tuntas KKM, Nilai Rata - rata untuk Siklus 1 yang dijadikan sebagai Pra Siklus adalah 43,14 dnegan 1 siswa yang tuntas KKM, Nilai Rata - rata untuk Siklus 2 yang dijadikan sebagai Pra Siklus adalah 59,71 dengan 21 siswa yang tuntas KKM dengan demikian untuk rata - rata ulangan harian baik Pra Siklus, Siklus 1 dan Siklus 2 tetap mengalami peningkatan dengan jumlah masing - masing siswa yang diatas KKM mengalami peningkatan. Selain itu hasil non tes juga menunjukkan adanya perubahan perilaku menjadi lebih baik dalam hal motivasi dan minat baca. Peserta didik menunjukkan respon dan aktivitas yang lebih baik dimulai dari Pra Siklus, Siklus I dan Siklus II. Dapat dilihat bahwa ada peningkatan pada setiap step / siklusnya, dimana memperlihatkan hal yang menunjukkan keberhasilan dalam penerapam model pembelajaran dan media madding dalam pembelajaran ekonomi kompetensi dasar Perdagangan Internasional ini.
\end{abstract}

Kata kunci: Kemampuan Kognitif, Konsep Perdagangan Internasional, Hasil Belajar, Model Pembelajaran Inquiry, Media Madding

\section{ABSTRACT}

The research objectives of this class are: (1) to describe the learning process using the Inquiry Learning Model to improve the Cognitive Ability of the International Trade Concept Students of Class XI Social Sciences 2. (2) to describe how much the students' increase in the cognitive ability of the international trade concept is indicated by the value of the results. student learning using the Inquiry Learning Model for Class XI Social Sciences 2. (3) Describing behavioral changes that accompany cognitive abilities or understanding the concept of International Trade is too broad and often updated with regard to International Trade information related to the condition of the country in society, by using Inquiry Learning Model for Class XI Social Sciences 2 Students using the Inquiry Learning Model for Class XI Social Sciences 2 Students. SMA N 2 Mranggen. Based on the results of the study, it is known that the average score for the Daily Test which is used as the Pre-Cycle is 38.43, only 1 student has completed the KKM, the average score for Cycle 1 which is used as the Pre-Cycle is 43.14 with 1 student who completes KKM, the average value for Cycle 2 which is used as Pre-Cycle is 59.71 with 21 students who complete the KKM. Thus, the average daily test for both Pre-Cycle, Cycle 1 and 
Cycle 2 continues to increase with the number of each student. above the KKM has increased. In addition, non-test results also showed a change in behavior for the better in terms of motivation and interest in reading. Students show better responses and activities starting from Pre-Cycle, Cycle I and Cycle II. It can be seen that there is an increase in each step / cycle, which shows things that show success in the application of learning models and media madding in learning economics of the basic competencies of International Trade.

Keywords: Cognitive Ability, International Trade Concept, Learning Outcomes, Inquiry Learning Model, Media Madding

\section{PENDAHULUAN}

Pembelajaran Ekonomi kurang efektif dan memberikan hasil belajar yang memuaskan. Masalah utama yang menjadi bahan penelitian ini adalah Peningkatan Kemampuan Kognitif pada materi Perdagangan Internasional peserta didik masih rendah, hal tersebut dikarenakan belum menggunakan model pembelajaran yang tepat dan memanfaatkan media secara efektif. Penelitian ini diharapkan mampu memberikan saran atas masalah diatas dengan melaksanakan pembelajaran materi Perdagangan Internasional dengan menggunakan model pembelajaran inquiry dan memanfaatkan media madding dalam proses pembelajaran ekonomi ini.

Penelitian ini menggunakan desain penelitian tindakan kelas yang dilaksanakan dalam dua siklus.Siklus I dan siklus II, masing-masing sikuls terdiri atas perencanaan, tindakan, pengamatan, dan refleksi. Subjek penelitian adalah kemampuan kognitif konsep kompetensi dasar Perdagangan Internasional dalam pelajaran ekonomi peserta didik XI IPS 2 yang berjumlah 36 siswa terdiri atas siswa putra dan siswa putri.

Menurut Kunandar (2013), Kegiatan guru setelah melakukan proses belajar mengajar adalah melakukan penilaian hasil belajar. Penilaian hasil belajar secara esensial bertujuan untuk mengukur keberhasilan peserta didik dalam penguasan kompetensi yang telah ditentukan. Dengan demikian, penilaian hasil belajar itu sesuatu yang sangat penting. Dengan penilaian itu bisa melakukan refleksi dan evaluasi terhadap kuallitas pembelajaran yang telah dilakukan. Apakah metode, strategi, media, model pembelajaran dan hal lain yang dilakukan dalam proses belajar mengajar itu tepat dan efektif atau sebaliknya bisa dilihat dari hasil belajar yang diperoleh peserta didik. Jika hasil belajar peserta didik dalam ulangan harian atau formatif masih di bawah kriteria

Ketuntasan Minimal (KKM), maka bisa dikatakan proses pembelajaran yang dilakukan gagal. Dan jika hasil belajar peserta didik di atas KKM, maka bisa dikatakan proses pembelajaran yang dilakukan guru berhasil. Menurut Kunandar, (2013) Tujuan dan manfaat hasil penilaian peserta didik secara esensial adalah untuk mengetahui daya serap peserta didik dalam pembelajaran dan keberhasilan guru dalam pembelajaran

Pembelajaran tuntas yang dimaksudkan dalam pelaksanaan kurikulum 2013 adalah pola pembelajaran yang menggunakan prinsip ketuntasan secara individual. Dalam hal ini pemberian kebebasan belajar serta mengurangi kegagalan peserta didik dalam belajar, strategi belajar tuntas menganut pendekatan individual, dalam arti meskipun kegiatan belajar ditunjukkan pada sekelompok peserta didik (kelas), tetapi mengakui dan melayani perbedaanperbedaan perorangan peserta didik sedemikian rupa sehingga dengan penerapan pembelajaran tuntas memungkinkan berkembangnya potensi masing-masing peserta didik secara optimal. Dasar pemikiran dari belajar tuntas dengan pendekatan individual ialah adanya pengakuan terhadap perbedan individual masing-masing peserta didik.

Menurut Mulyasa, Inquiry adalah cara menyadari apa yang telah dialami. Sistem belajar mengajar ini menurut siswa berpikir. Model pembelajaran ini menempatkan siswa pada situasi yang melibatkan mereka pada kegiatan intelektual, dan memproses pengalaman belajar menjadi sesuatu yang bermakna.

Tujuan pelaksanaan inquiry adalah mengarah pada peningkatan kemampuan baik dalam bentuk kognitif, afektif, maupun psikomotor. Hal ini tidak terlepas dari perencanaan 
(kurikulum) pengajaran, sehingga tujuan pengajaran dapat tercapai sesuai pemilihan metode yang dilakukan.

Pada metode inquiry yang dipelajari siswa merupakan hal baru, belum diketahui sebelumnya. Oleh karena itu beberapa instruksi atau petunjuk perlu diberikan kepada siswa apabila mereka belum mampu menunjukkan ide atau gagasan. Dalam menemukan konsep yang dipelajari, sebaiknya siswa tidak tersesat atau merasa kesulitan. Bimbingan tersebut dapat dimulai dengan mengajukan beberapa pertanyaan dan dengan memberikan sedikit informasi secara singkat.

Aspek kognitif menjadi aspek utama dalam banyak kurikulum pendidikan dan menjadi tolok ukur penilaian perkembangan anak. Kognitif yang berasal dari bahasa latin cognitio memiliki arti pengenalan, yang mengacu kepada proses mengetahui maupun kepada pengetahuan itu sendiri.

Menurut Nizwardi (2016) mengenai Pemilihan Media Pembelajaran, Dalam pemilihan ada beberapa pertimbangan atau kriteria yang dapat digunakan agar dapt terpenuhinya kebutuhan dan tercapainya tujuan pembelajaran. Kriteria umum yang perlu diperhatikan diantaranya: tujuan pembelajaran, Kesesuaian materi, Karakteristik siswa. Gaya belajar siswa (auditif, visual dan kinestik), Lingkungan, Ketersediaan fasilitas pendukung.

Majalah dinding adalah salah satu jenis media komunikasi massa tulis yang paling sederhana. Disebut majalah dinding karena prinsip dasar majalah terasa dominan di dalamnya, sementara itu penyajiannya biasanya dipampang pada dinding atau yang sejenisnya.

Dunia akan menjadi luas bila kita senang membaca. Untuk itu, kegemaran membaca harus ditanamkan. Dalam hal ini mading punya andil yang besar. Mading dapat tampil setiap saat tanpa dihadang oleh sejumlah kesulitan. Mading dapat diterbitkan oleh siapa saja dalam jangka waktu yang relatif bebas tergantung animo pembaca. Kalau pembacanya menghendaki, mading dapat ditampilkan setiap hari dengan materi tulisan yang bersifat aktual sesuai lingkungan. Apabila minat baca dan atensi menulis masyarakat sedang-sedang saja, mading dapat diganti tiap bulan atau tiap-tiap minggu.

Melalui pemikiran tersebut di atas penulis berpikir untuk menggunakan Madding (Majalah Dinding) ini sebagai media dalam pembelajaran dalam Kompetensi Dasar Perdaganagan Internasional. Topik Perdagangan Internasional ini bisa menjadi topik yang aktual setiap harinya dan melalui pembelajaran ini diharapkan siswa selalu update mengenai perkembangan dalam konsep Perdagangan Internasional ini dan pada akhirnya model pembelajaran inquiry berhasil diterapkan dalam upaya meningkatkan hasil belajar peserta didik.

Berdasarkan uraian tersebut, dapat dipahami bahwa pemanfaatan media Madding (Majalah Dinding) dapat menarik minat atau daya tarik dan memudahkan peserta didik mendeskripsikan sesuatu. Dengan kata lain, pembelajaran materi Perdagangan Internasional dengan bantuan media Madding (Majalah Dinding) dapat meningkatkan kemmapuan kognitif peserta didik. Oleh karena itu, penelitian ini dilaksanakan untuk mengetahui peningkatan kemampuan kognitif peserta didik dengan melaksanakan pembelajaran kosnep Perdagangan Internasional dengan pemanfaatan media Madding (Majalah Dinding)

\section{METODE PENELITIAN}

Pada penelitian tindakan kelas ini penulis laksanakan dalam 2 siklus, masing-masing siklus akan dilakukan 2 kali pertemuan dan masing-masing pertemuan 2 X 45 menit, ini berarti akan ada 4 kali pertemuan pada dua siklus tersebut. Adapun siklus atau prosedur pelaksanaan tersebut penulis rancang sebagai berikut :Gambar 1. SIklus 1 dan SIklus 2 


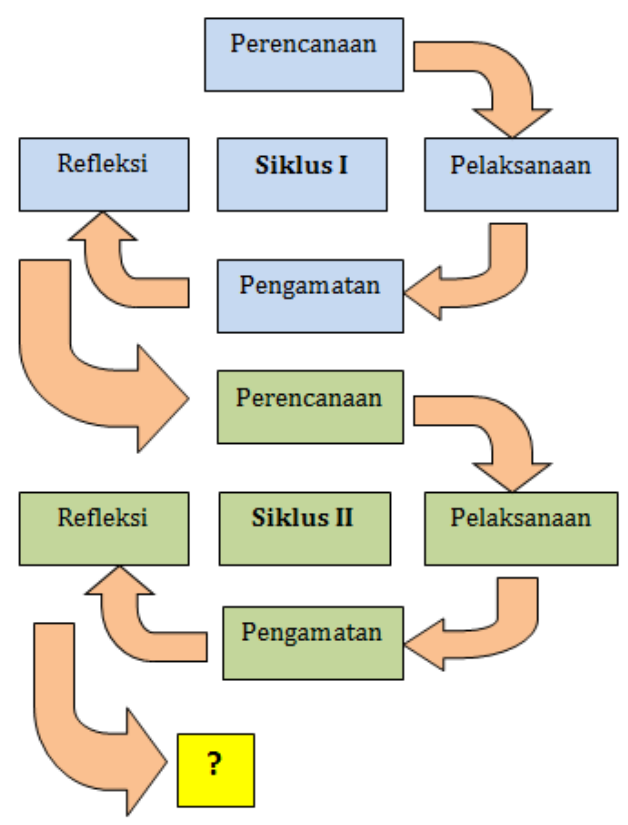

\section{Gambar 1. Skema Penelitian Tindakan Kelas}

Pada penelitian ini penulis menggunakan teknik pengumpulan data wawancara, observasi atau pengamatan, dan pemberian kuesioner sebelum dan sesudah tindakan, dikarenakan jenis data pada penelitian ini adalah data kualitatif. Secara rinci tentang fokus penelitian, indikator yang diteliti, jenis data, teknik pengumpulan data, instrument, dan sumber data tersebut dapat penulis paparkan dalam diagram dibawah ini :

Indikator keberhasilan dari pemanfaatan media Madding (Majalah Dinding ) dalam peningkatan keterampilan Perdagangan Internasional ini adalah sebagai berikut : (a). Hasil wawancara menunjukkan bahwa peserta didik merasa senang dan merasa terbantu dengan pemanfaatan media Madding (Majalah Dinding ) untuk meningkatkan keterampilan Perdagangan Internasional, (b) Berdasarkan pengamatan peserta didik mampu mendeskripsikan konsep Perdagangan Internasional dengan bantuan media Madding ( Majalah Dinding ) secara lisan, (c). Peserta didik mempunyai perasaan senang dan pikiran yang positif terhadap penelitian ini dengan hasil kuestioner.

Observasi pada penelitian ini melalui data non tes diperoleh dari pedoman catatan harian, pedoman deskripsi perilaku, pedoman wawancara, dokumentasi video, dan dokumentasi foto. Observasi melalui data non tes diperoleh melalui deskripsi perilaku yaitu meneliti tingkah laku siswa selama proses pembelajaran berlangsung. Observasi melalui dokumentasi foto dapat memotret setiap aktivitas dalam pembelajaran, sedangkan dokumentasi video dapat merekam jalannya pembelajaran. Setelah pembelajaran berakhir, peneliti menyuruh siswa untuk menulis kesan dan tanggapan melalui catatan harian serta menilai teman lain dalam setiap kelompok. Selain itu, peneliti juga melakukan wawancara dengan siswa yang mempunyai kemampuan rendah, sedang, dan tinggi dalam mendeskripsikan konsep Perdagangan Internasional melalui media Madding.

Tahap observasi dilakukan untuk mengetahui minat dan kesan siswa terhadap pembelajaran saat memahami dan mendeskripsikan konsep Perdagangan Internasional melalui media Madding. Selain itu, pada tahap ini dapat diketahui kesulitan siswa dalam menulis petunjuk serta kekurangan-kekurangan dalam proses pembelajaran. Kekurangan-kekurangan yang terdapat pada hasil observasi siklus I pada akhirnya dapat diperbaiki pada siklus II.

Pencapaian kompetensi peserta didik sudah di atas kompetensi di atas KKM, dari penelitian ini sudah menunjukkan perilaku yang positif yang ditunjukan dengan antusias dan motivasi siswa lebih tinggi daripada sebelumnya. Dengan demikian penelitian ini dihentikan di 
siklus Prosedur analisis data meliputi : (a) Mengadakan interprestasi terhadap data yang sudah diambil, (b) Mengevaluasi dan melakukan analisis dengan cermat Tindakan pada siklus I d an siklus II

\section{HASIL DAN PEMBAHASAN}

Hasil penelitian tindakan kelas ini diperoleh dari beberapa tindakan yaitu tindakan pra siklus, tindakan siklus I, dan tindakan pada siklus II. Hasil tes pra siklus dilaksanakan sebelum siklus I maupun siklus II, sedangkan hasil pada siklus I dan Siklus II berupa konsep mengenai Perdangangan Internasional. Sedangkan hasil non tes didapatkan dari hasil catatan guru, pengamatan, dan dokumen foto.

Hal-hal yang dibahas berupa proses selama pembelajaran, peningkatan kogniti, dan pembahasan perubahan tingkah laku peserta didik pada siklus I dan siklus II setelah melaksanakan pembelajaran ekonomi materi Perdagangan Internasional dengan menggunakan media Madding ( majalah dinding ).

Hasil penelitian pra siklus siklus I, dan siklus II dapat dijelaskan sebagai berikut:

\section{Hasil Penelitian Pra Siklus}

Hasil tes pra siklus diperoleh berdasarkan pengamatan dan wawancara selama pelaksanaan pembelajaran Ekonomi Kelas XI IPS 2 SMA Negeri 2 Mranggen dan kondisi awal, yaitu sebelum dilaksanakan pembelajaran ekonomi konsep Perdagangan Internasional dengan menggunakan bantuan media Madding. Hasil tes pra siklus berfungsi untuk mengetahui seberapa besar kemampuan peserta didik dalam konsep ini.

\section{Hasil Penelitian Siklus 1}

Berdasar pada hasil pra siklus diatas, maka kegiatan siklus I ini merupakan kegiatan tindak lanjut dari pra siklus tersebut.Kegiatan siklus I dilaksanakan dengan menerapkan pembelajaran pada materi pembelajaran ekonomi konsep Perdagangan Internasional dengan menggunakan bantuan media Madding selama 2 kali pertemuan. Pemaparan hasil penelitian diawali dengan memaparkan proses pembelajaran ekonomi konsep Perdagangan Internasional dengan menggunakan bantuan media Madding berdasarkan pada hasil instrumen dan hasil belajar siswa peserta didik, catatan harian guru.

Pemaparan selanjutnya mengenai peningkatan pengetahuan kognitif pada materi descriptive berupa nilai tes keterampilan berbicara setelah peserta didik melaksanakan proses pada materi pembelajaran ekonomi konsep Perdagangan Internasional dengan menggunakan bantuan media Madding. Sementara itu penjelasan mengenai perubahan perilaku berupa Hasil perilaku peserta didik pada siklus I dapat dijelaskan dalam lima karakter peserta didik dalam diskusi kelas yaitu meliputi Penguasaan materi diskusi, Kemampuan menjawab pertanyaan, Kemampuan mengolah kata, Kemampuan menyelesaikan masalah.

Perubahan perilaku nampak dalam kemampuan Bekerja Sama, Jujur, Tanggung Jawab dan Disiplin.

\section{Analisa Nilai Siklus 1}

Berdasarkan data di atas hanya ada 2 siswa di atas KKM 70 dari 35 siswa . Hal ini tentu sangat memprihatinkan, dan setelah dianalisa salah satu penyebabnya adalah kurangnya kemampuan siswa dalam memahami konsep pembelajaran ekonomi. Nilai rata - rata yang diperoleh hanya 43,4. Meski hal ini mengalami kenaikan dari rata - rata nilai pra siklus yaitu 38,4 3 dan jumlah siswa yang mencapai KKM hanya 1 orang.

Hal diatas menjadi refleksi bagi guru sebagai peneliti untuk memperbaiki pembelajaran pada siklus II.

Adapun setelah dilakukan siklus II dalam pembelajaran ekonomi konsep Perdagangan Internasional ini dicapai hasil sebagai berikut :

\section{Hasil Penelitian Siklus 2}

Dari hasil siklus II pembelajaran ekonomi konsep Perdagangan Internasional dengan menggunakan media Madding (Majalah Dinding) ada 21 siswa di atas KKM 70 dan rata - rata 
yang diperoleh adalah 59,71, sehingga dari hasil siklus I dan siklus II terjadi peningkatan jumlah anak yang mnecapai KKM juga meningkatnya rat a- rata hasil belajar yang diperoleh siswa sebesar 0,27 atau 27\%. Meski rata -rata hasil belajar siswa belum mencapai KKM yang diharpkan namun penerapam model pembelajaran dengan media Madding ini bisa dikatakan sudah berhasil karena ada peningkatan dalam jumlah anak yang mencapai KKM dan rata-rata KKM.

Dari hasil penelitian di atas yang dimulai dari Pra Siklus, Siklus I dan Siklus II. Dapat dilihat bahwa ada peningkatan pada setiap step / siklusnya. Hal ini yang jelas paling terlihat adalah dari bagian yang berwarna hijau, dimana memperlihatkan hal yang menunjukkan keberhasilan dalam penerapan model pembelajaran dan media madding dalam pembelajaran ekonomi kompetensi dasar Perdagangan Internasional ini.

Tabel 2. Tabel Perkembangan hasil belajar siswa pada tahap pra siklus, siklus 1 dan siklus 2 dilihat dari KKM ( Kriteria Ketuntasan Minimal )

\begin{tabular}{|c|c|c|}
\hline pra siklus & siklus 1 & siklus 2 \\
\hline 1 & 2 & 21 \\
\hline
\end{tabular}

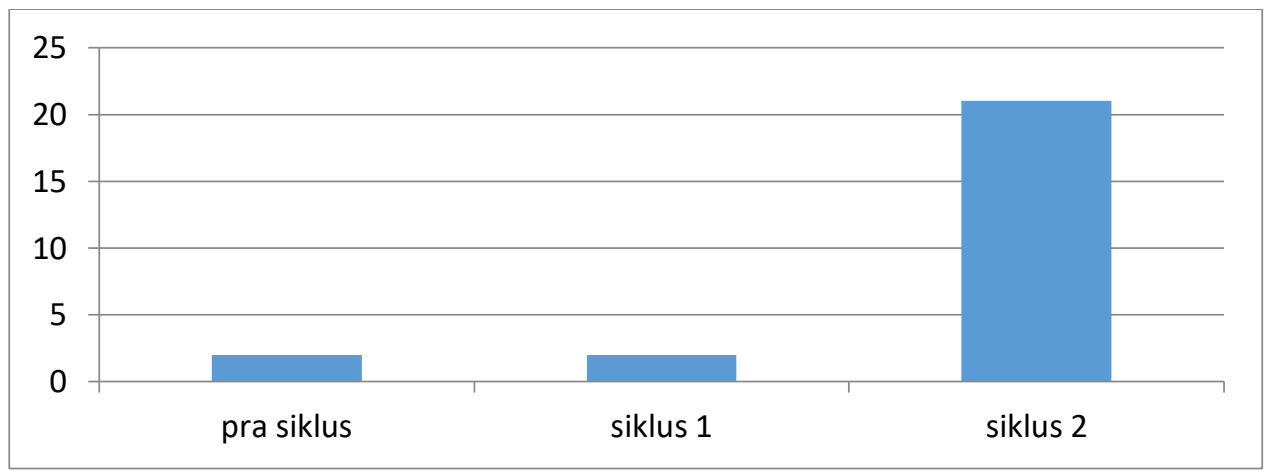

Grafik 3 : Perkembangan hasil belajar siswa pada tahap pra siklus, siklus 1 dan siklus 2 dilihat dari KKM ( Kriteria Ketuntasan Minimal )

Hasil perilaku peserta didik pada siklus I dapat dijelaskan dalam lima karakter peserta didik yaitu Bekerja Sama, Jujur, Tanggung Jawab, Disiplin. Hasil perilaku merupakan hasil non tes siklus I yang diperoleh melalui perilku peserta didik, catatan harian guru, catatan harian peserta didik, wawancara, dan dokumen foto.

Keaktifan peserta didik dalam bekerja sama merupakan bagian penting yang harus ditanamkan kepada para peserta didik, agar menjadi pribadi yang aktif dan dinamis. Keaktifan peserta didik dapat dilihat dari deskripsi tingkah laku, hasil pengamatan, catatan guru yang halhal tersebut dapat digunakan sebagai bahan pertimbangan untuk menentukan keaktifan peserta didik.

Hasil pengamatan dari guru menunjukkan bahwa sebagian besar peserta didik dengan antusias dan penuh perhatian memperhatikan ketika guru sedang menjelaskan, menerangkan dan memberikan

\section{Jujur}

Pada aspek kejujuran cukup bagus. Hal ini terlihat dalam siswa menyelesaikan semua tugas- tugas individunya.

\section{Tanggung Jawab}

Peserta Didik memiliki aspek Tanggung Jawab merupakan aspek yang sangat menentukan dan sangat berpengaruh terhadap kualitas peserta didik. Peserta didik terlihat bertanggung jawab dalam menyelesaikan tugas-tugasnya. 


\section{Disiplin}

Aspek lain yang dinilai pada siklus I ini adalah kedisiplinan. Hal ini dapat diamati ketika peserta didik menyelesaikan tugas dengan tepat waktu dan dari hasil yang dikumpulkan sesuai dengan kriteria dan indikator yang disampaikan guru.

\section{Pembahasan}

Mulyani (2010) dalam penelitiannya yang berjudul "Strategi Penanaman Pendidikan Berkarakter dalam Mata Pelajaran Bahasa Indonesia Melalui Penulisan Mading pada Siswa Kelas II SMP 1 Cianjur" menunjukkan hasil bahwa mading memiliki peranan yang sangat strategis dalam peningkatan pemahaman pendidikan berkarakter dalam pembelajaran Bahasa Indosesia. Itu ditunjukkan dengan peningkatan yang berarti setelah diberi pembelajaran bahasa Indonesia yang berorientasi pada pendidikan karakter dalam mading.

Dalam Jurnal yang ditulis Ari, Indriani, Ayu, "Nilai-Nilai Karakter Bangsa dalam Tulisan Siswa pada Majalah DInding di SMP Negeri 1 Seririt”, Jurusan Pendidikan Bahasa dan Sastra Indonesia. Fakultas Bahasa dan Seni. Universitas Pendidikan Ganesha, Singaraja 2014. Hasil penelitian menunjukkan bahwa terdapat penerapan nilai-nilai karakter bangsa dalam tulisan siswa pada majalah dinding di SMP N 1 Seririt, yang diwujudkan dengan tulisantulisan di majalah dinding khususnya pada rubric berita, tajuk rencana, opini, profil dan cerita hiburan. Delapan belas nilai karakter, yaitu: religius, jujur, toleransi, disiplin, kerjakeras, kreatif, mandiri, demokratis, rasa ingin tahu, semangat kebangsaan, cinta tanah air, menghargai prestasi, bersahabat, cinta damai, gemar membaca, peduli lingkungan, peduli sosial, dan tanggung jawab.

Dalam Jurnal Pemanfaatan si Macan untuk Meningkatkan Kreativitas berfikir PesertaDdidik pada mata Pelajaran Geografi di kelas X IIS 2 SMAN 1 Purwantoro Tahun pelajaran 2016/2017, Jurnal Pendidikan Ilmu Pengetahuan Sosial Indonesia Volum 1 Nomor 2 bulan September 2016, yang ditulis Dony Hasil penelitian menyatakan bahwa Pemanfaatan Si Macan (Mading Cakap Aktif dan Menyenangkan) dapat meningkatkan kreativitas berfikir peserta didik di kelas XIIS 2 SMAN 1 Purwantoro tahun pelajaran 2016/2017 pada indikator Fluency, Flexibility dan Novelty.

\section{KESIMPULAN}

Simpulan berdasarkan hasil penelitian pembelajaran ekonomi dengan model pembelajaran Inquiry berbasis media Madding adalah sebagai berikut. (1) Proses pembelajaran pada siklus I dan siklus II berlangsung melalui alur atau tahap tahap yang sama yaitu masingmasing menerapkan tiga kali pertemuan, dengan metode pembelajaran yang digunakan pada siklus I dan Siklus II sama. (2) Pelaksanaan proses pembelajaran pada siklus I sudah berlangsung dengan baik namun masih ditemukan beberapa kelemahan, dan berdasarkan refleksi siklus I, maka peneliti melakukan perbaikan pada pelaksanaan pembelajaran siklus II sehingga pembelajaran pada siklus II sudah berlangsung dengan sangat baik.

\section{DAFTAR PUSTAKA}

Ari, Indriani, Ayu. (2014). "Nilai-Nilai Karakter Bangsa dalam Tulisan Siswa pada Majalah DInding di SMP Negeri 1 Seririt”, Jurusan Pendidikan Bahasa dan Sastra Indonesia. Fakultas Bahasa dan Seni. Universitas Pendidikan Ganesha, Singaraja.

Dony. (2016). Pemanfaatan si Macan untuk Meningkatkan Kreativitas berfikir Peserta Ddidik pada mata Pelajaran Geografi di kelas X IIS 2 SMAN 1 Purwantoro Tahun pelajaran 2016/2017. Jurnal Pendidikan Ilmu Pengetahuan Sosial Indonesia, Volum 1 Nomor 2, Page 38-42 p-ISSN: 2477-6254 e-ISSN: 2477-8427

Mulyasa, E., \& Profesional, M. G. (2005). Menciptakan pembelajaran kreatif dan menyenangkan. Remaja Rodaskarya, Bandung

Nizwardi. (2016). Media dan Sumber Pembelajaran. Kencana : Jakarta 